\title{
Analysis on the Influence of Compensation and Leadership on Job Satisfaction and Its Effect on Job Performance
}

\author{
Ferryal Abadi \\ Institut Teknologi \& Bisnis Kalbis \\ Jakarta, Indonesia \\ ferryal.abadi@kalbis.ac.id
}

\begin{abstract}
The aim of this research is to analyze and study the influence of compensation and leadership on job satisfaction and its impact on job performance. The population and sample of this research are 84 managers at Nusantara Bonded Area in Jakarta who are demanded to be in the middle position between employees and employers. Data collection uses questionnaire, interview, observation, and documentation. Path analysis is used in the SPSS data processing. The results of this research show that compensation and job satisfaction significantly influence job performance whereas leadership does not influence job performance.
\end{abstract}

Keywords: Compensation, Leadership, Job Satisfaction, Job Performance.

\section{I.INTRODUCTION}

Human resource has been being a very important factor to advance a company. Without qualified human resources we will not have quality products and services. Yet, many companies have not understood how important human resource is. Employees are considered only as a cost because the companies should pay their salary, overtime, health care benefit, and other expenses every month.

As an appreciation for the performance dedicated by employees, then the company provides compensation as a source of living for those employees. This compensation is always related to the quantity, quality, and usefulness of services the employees dedicate to the company where they work. The compensation provided for them will influence how far the organization's goal can be achieved, even it can influence the viability of that company.

Leadership in an organization is important because the role of a leader is to be the agent of change. The leadership of a manager or a supervisor is a determining factor for the success of a company at the operational level. Therefore, a manager or a supervisor should become a success driver in achieving the organizational goals.

Some previous researches prove that leadership has a positive and significant effect on employee's job satisfaction as carried out[1]. [2]. Which state that transactional and transformational leadership styles positively and significantly influence employee's job satisfaction. Whereas a different

\author{
Joseph MJ Renwarin \\ Institut Teknologi \& Bisnis Kalbis \\ Jakarta, Indonesia
}

result stating that transactional leadership style negatively influences employee's job satisfaction and transformational leadership style is more suitable for govermental organizations or institutions.[3]

Job satisfaction is a very important concept in the human resource management. Herzberg's research finds the factors which cause satisfaction such as achievement, recognition, the job itself, responsibility and progress. Another opinion states that job satisfaction is an emotional condition which is pleasurable or unpleasurable by which employees perceive their job [4].

Previous researches also prove the influence of job satisfaction on employee's performance. That job satisfaction has a significant influence on employee's performance. Employees will be satisfied when they get what they want. Job satisfaction has a relationship with employee's inner feeling. Job satisfaction refers to all the positive or negative feelings of each individualal toward their job. [5][6] Appraisal on employee's job performance, frequently called performance appraisal, should also be done in order to see how far the success of training and motivating employees. [7]. A company organization is established because it has a specific goal that wants and must be achieved. In achieving its goals every organization influenced organizational behavior. One of the most common activities done in the organization is the performance of employees, namely how employees do everything related to work or role in the organization.

Performance or performance is a description of the level of achievement of the implementation of an activity or policy program in realizing the goals, goals and mission of the organization in pour through the strategic planning of an organization.

Nusantara bonded area is a region located in North Jakarta is a barometer of garment companies, especially in Jabotabek in every policy of other garment companies such as wages due to $70 \%$ who rent in this region is the garment industry with the status of foreign capital investment originating from South Korea. 


\section{II.THEORY}

\section{Compensation}

Compensation is one of the important factors paid much attention in many organizations to attract and retain qualified human resources. Organizations compete for qualified human resources, because the quality of work output is determined by the competence of human resources as required.Compensation can be divided into:

Financial Compensation consists of indirect compensation and direct compensation. Direct compensation consists of paying employees in the form of wages, salaries, bonuses, or commissions. Indirect compensation or benefit, consisting of all payments not covered by direct financial compensation including entertainment, various insurance services such as, child care or religious concern, and so on.

Non-financial compensation, ie non-financial awards such as praise, self-respect and recognition that can affect employee motivation, productivity, and satisfaction. Based on the above descriptions can be concluded that the compensation is one element of financing (cost) organization / company Very important, because it will affect the basic price of its products, either in the form of goods or services marketed. [8]

Other compensations can be given non-financially in the form of appreciation such as more challenging jobs, wider working hours, and prestigious offices. According to Schuler and Jackson, non-financial compensation takes the form of career reward (secure feeling, self-development, career).

\section{Leadership}

Leadership is an ability to influence other people's behaviour toward a certain direction.

Define leadership as a process in which an individual influences the other group members toward the achievement of group or organizational goals that have been set. Meanwhile, a leader is an individual in a group or organization who is the most influential to the other individuals.[9]

That leadership is an ability to influence a group toward achieve a vision and a series of goals.[10] Whereas define leadership as a process in which an individual influences other people to achieve common goals.[11]

Leadership as the use of power and influence to direct the followers' activities toward achieving the goals. The direction can influence the interpretation of the followers' incidents, their job activity organization, their commitment to the main goal, their relationship with the followers or their access to cooperation and support from other work units. [12]

\section{Job Satisfaction}

With job satisfaction an employee can perceive whether his job is pleasurable or not to be performed. Job satisfaction is a generalization of attitudes on the job. Various attitudes shown by an individual on his job reflects both pleasurable and unpleasurable experiences in his job as well as his hope for future experience.[13].
Jobs satisfactions as a pleasurable feeling that result from the perception that one's important job values. Based on this definition, job satisfaction consists of three important aspects: a function of value, employee's perception, and the difference with what they should obtain. Job satisfaction is one of the important aspects the management of an organization should understand.[14].

\section{Job Performance}

Job performance is an approach to implement a performance appraisal on the employees where there are some factors, namely:

1. The object of appraisal is human being who has not only certain abilities but also weaknesses and defficiencies.

2. Appraisal is carried out using a set of certain standards which are realistic and directly related to one's job, and the criteria are objectively set and implemented. [15]

Performance is a comparison between one's performance and the expected results.[16] Performance appraisal indicates how far the results are achieved by an employee. Employee's job performance is the information used as the base for making decisions concerning promotion and salary. [17]. Performance appraisal is a systematic assessment on an employee done by his superordinate or some other experts who understand the job performed by the employee. Performance appraisal is a useful tool not only for evaluating employees' job but also developing and motivating them. [18] A slightly different opinion says that performance appraisal is a process through which organizations evaluate or assess their employees' job performance; this activity can improve personnel's decisions and give feedbacks to employees about their job execution. [4]

\section{Research Model}

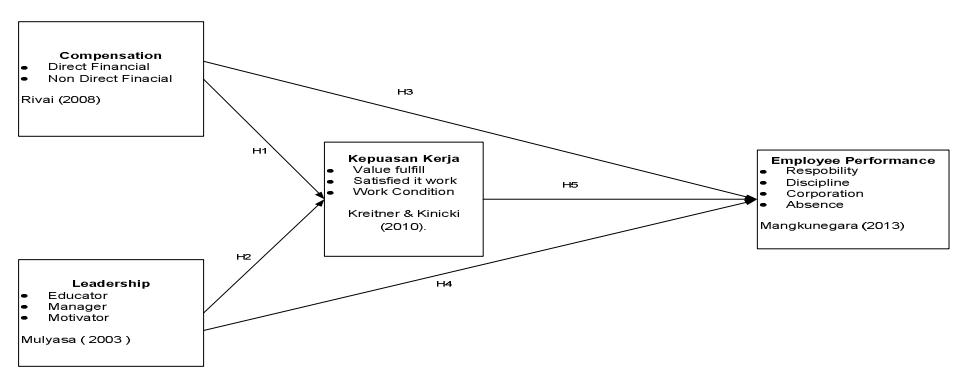

Figure 1 Research Model

\section{Hypotheses}

Based on the above framework, the hypothesis of this research can be formulated as follows:

1. H1 : Compensation significantly influences job satisfaction.:

2. H2 : Leadership significantly influences job satisfaction.

3. H3 : Compensation significantly influences job performance.

4. H4 : Leadership significantly influences job performance. 
5. H5 : Job satisfaction significantly influences job performance.

\section{III.RESEARCH METHOD}

\section{Type of Research}

This research is designed using descriptive method with quantitative approach. Descriptive statistic method is used to explain the phenomena happening to the research data. Meanwhile, quantitative method is used to explain the influence of independent variables on the dependent variable in this research.

\section{Population and Sample}

Population is understood as a generalization area consisting of objects/subjects with certain qualities and characteristics implemented by the researchers to be studied and then concluded. The population in this research comprises Human Resource Managers or Personnel Heads of the companies at Nusantara Bonded Area in Cakung, numbering 84 people.Sample is a part of population. But ini this research all the population becomes the sample.

\section{Discussion}

\section{Regression Equation}

$\mathrm{Y}=\mathrm{YX} 1+\rho \mathrm{YX} 2+\varepsilon 1 \ldots \ldots$. Substructural 1

$Z=\rho Z X 1+\rho Z X 2+\rho Z Y 3+\varepsilon 2 \ldots$ Substructural 2

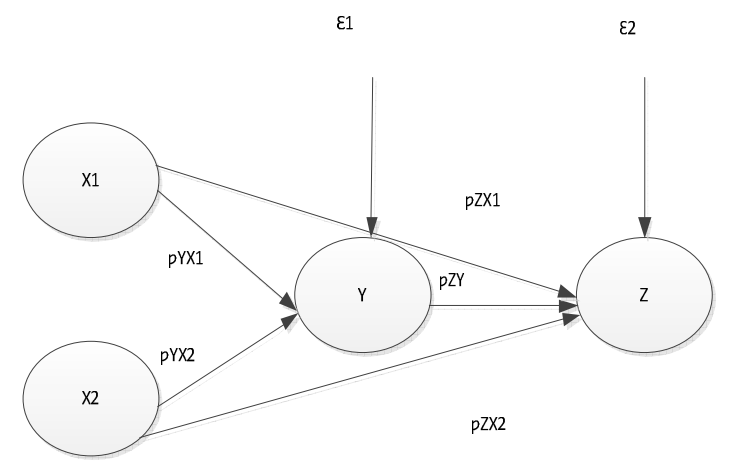

Figure 2 Path Design

\section{Substructural 1}

Table 1 Coefficient of Determination

\begin{tabular}{|c|c|c|c|c|}
\hline Model & $\mathrm{R}$ & $\begin{array}{c}\mathrm{R} \\
\text { Square }\end{array}$ & $\begin{array}{c}\text { Adjusted R } \\
\text { Square }\end{array}$ & $\begin{array}{c}\text { Std. Error of } \\
\text { the Estimate }\end{array}$ \\
\hline 1 & $.718^{\mathrm{a}}$ & .516 & .504 & 3.10432 \\
\hline
\end{tabular}

a. Predictors: (Constant), Leadership, Compensation

Simultaneously, compensation and leadership positively and significantly influence employee's job satisfaction. The value of simultaneous effect 0.516 or rounded to be $52 \%$ is contributed by the influence of compensation and leadership variables on job satisfaction. Whereas the rest $48 \%$ is influenced by other factors outside the model.
Table 2 Regression Analysis

\begin{tabular}{|c|c|c|c|}
\hline \multirow{2}{*}{ Model } & $\begin{array}{c}\text { Standardized } \\
\text { Coefficients }\end{array}$ & \multirow{2}{*}{$\mathrm{t}$} & \multirow{2}{*}{ Sig. } \\
\cline { 2 - 2 } & Beta & & \\
\hline (Constant) & & 6,268 & .000 \\
Compensation & .439 & 4,735 & .000 \\
Leadership & .376 & 4,065 & .000 \\
\hline
\end{tabular}

This simultaneous model happens significantly. It can be seen from the probability $(\mathrm{sig})<0.05$. Significance test is subsequently followed by individual test through statistic parameter $t$. The result of individual test indicates significant effect as well, regarding the obtained Sig $<0.05$ at $\mathrm{X}_{1}$ path and $\mathrm{Sig}<0.05$ at $\mathrm{X}_{2}$ path. This surely explains that compensation and leadership can simultaneously and partially become the variables that influence employee's job satisfaction. This empirical causal influence between compensation variable $\left(\mathrm{X}_{1}\right)$ and leadership $\left(\mathrm{X}_{2}\right)$ can be illustrated in substructural equation 1 .

$\mathrm{Y}=\rho \mathrm{YX} 1+\rho \mathrm{YX}_{2}+\rho \mathrm{Y} \varepsilon_{1}$ or

$Y=0.439 X_{1}+0.376 X_{2}+\varepsilon_{1}$

Hypothesis 1. Compensation significantly influences employee's job satisfaction. The value of partial and direct effect of compensation on job satisfaction is 0.439 or rounded to be $44 \%$. The degree of job satisfaction is influenced $44 \%$ by compensation whereas the rest $56 \%$ is explained by other factors outside the model.

Compensation is something received in return for employee's services to the company. Providing compensation as an implementation of human resource management related to all kinds of individual appreciation in exchange for performing organizational tasks is good, provided that the salary received by the employee equals to his job and work load, the salary is paid monthly on time, the company gives incentives to the employee with high achievement in his job, the company gives incentives to every employee in line with his job performance, the company gives bonus to every employee who accomplishes his job well and punctually, the company provides allowances to every employee according to his position, there are office facilities provided by the company that can support employee's work activities, and employee will be praised and recognized by the management if he shows good work output, the company makes its employees feel comfortable with the task and duty in his own work field so that they will be happier and love their job.

Hypothesis 2. Leadership significantly influences employee's job satisfaction. The value of direct effect

of leadership on job satisfaction is 0.376 or rounded to be $38 \%$. The degree of job satisfaction is influenced $38 \%$ by leadership whereas the rest $62 \%$ is explained by other factors outside the model. 
It means that good leadership will increase job satisfaction. This is in line stating that employee's job satisfaction is much influenced by the attitude of a leader in his leadership.[19]

Leadership takes a part in contributing job satisfaction to employees because they also participate actively in sharing opinion in order to formulate the company's policies. Authoritarian leadership causes low job satisfaction. Leadership is an effort of a leader in directing people to be willing to and able to work and achieve the goals set by the organization. Good leadership is expected to be able to direct, drive as well as influence the group members to participate in formulating and achieving the organizational goals. A leader should pay attention to his subordinates' job satisfaction. If leadership runs well, where the leader is liked by the employees and their wants can be fulfilled, it will increase job satisfaction and encourage employees to work well.

Table 3 Coefficient of Determination

\begin{tabular}{|c|c|c|c|c|}
\hline Model & $\mathrm{R}$ & $\begin{array}{c}\mathrm{R} \\
\text { Square }\end{array}$ & $\begin{array}{c}\text { Adjusted R } \\
\text { Square }\end{array}$ & $\begin{array}{c}\text { Std. Error of } \\
\text { the Estimate }\end{array}$ \\
\hline 1 & $.695 \mathrm{a}$ & .482 & .463 & 3.35006 \\
\hline
\end{tabular}

Table 4 Regression Analysis

\begin{tabular}{|c|c|c|c|}
\hline \multirow{2}{*}{ Model } & $\begin{array}{c}\text { Standardized } \\
\text { Coefficients }\end{array}$ & \multirow{2}{*}{$\mathrm{t}$} & Sig. \\
\cline { 2 - 2 } & Beta & & \\
\hline (Constant) & & .939 & .351 \\
Compensation & .297 & 2.728 & .008 \\
Leadership & -.045 & -.423 & .673 \\
Job Satisfaction & .495 & 4.280 & .000 \\
\hline
\end{tabular}

\section{Substructural 2}

\section{Structural Equation 2}

$$
\begin{aligned}
& \mathrm{Y}=\rho \mathrm{YX} 1+\rho \mathrm{YX} 2+\rho \mathrm{YX} 3+\mathrm{E} 2 \\
& \ldots \ldots \ldots \ldots \text {.Substructural } 2 \\
& \mathrm{Y}=0.297 \mathrm{X} 1-0.045 \mathrm{X} 2+0.495 \mathrm{X} 3+\mathrm{C} 2
\end{aligned}
$$

Hypothesis 3. Compensation significantly influences job performance. The value of compensation's effect on performance is 0.297 or rounded to be $30 \%$. It means the degree of job performance can only $30 \%$ be influenced by compensation whereas the rest $70 \%$ is influenced by other factors outside the model.

One way for the management to improve job performance, to motivate employees and to increase job satisfaction. In short, compensation is something received by employees in exchange for their work. [20]
Hypothesis 4. In direct relationship, leadership does not significantly influence employee's job performance. The value of its effect on job performance is -0.045 .

Leadership is also needed by subordinates, especially those who are eager to give contribution to achieving the organizational goals. They need a leader as external motivator to keep the organizational goals in line with their individual goals.

Thus, it can be concluded that a leader of an organization is especially a motivator for his subordinates. In this research, the leaders seem not to function well so that it is not significant.

Hypothesis 5. Job satisfaction significantly influences job performance. The value of job satisfaction's effect on job performance is 0.495 or rounded to be $50 \%$. It means that the degree of job performance can be $50 \%$ influenced by job satisfaction whereas the rest $50 \%$ is influenced by other factors outside the model.

It is frequently assumed that the employees who obtain job satisfaction will perform their job better. In many cases, there are frequently positive relationships between job satisfaction and high job performance, but they are not always strong enough and significant." Furthermore, he argues that "higher job satisfaction results mainly from job performance", not the contrary [4]. Better job performance results in higher appreciation. If the job is perceived fair and satisfying, then employee's job satisfaction will increase because they get proportional appreciation in acordance with their job performance. In the other hand, if appreciation is regarded unsatisfying for the degree of their job performance, job dissatisfaction tends to happen. Subsequently, such a job satisfaction or dissatisfaction becomes a feedback which will influence the future job performance. Thus, the relationship between job performance and job satisfaction is a continuous system."

From the three variables used as the predictors of performance, it is job satisfaction as the strongest variable that influences performance compared to the two other

\begin{tabular}{|c|c|c|c|c|}
\hline Model & $\begin{array}{c}\text { Coefficien } \\
\text { t of Path }\end{array}$ & $\mathrm{T}$ & $\mathrm{p}$ & R2 \\
\hline Substuctural 1 & $\begin{array}{c}(\mathrm{X} 1, \mathrm{X} 2 \text { to } \\
\mathrm{Y})\end{array}$ & & & \\
\hline $\mathrm{X} 1$ (pYX1) & 0.439 & 4,735 & 0.000 & \multirow[t]{2}{*}{0.516} \\
\hline $\mathrm{X} 2$ (pYX2) & 0.379 & 4,065 & 0.000 & \\
\hline $\begin{array}{c}\text { Substructural } \\
2\end{array}$ & $\begin{array}{l}(\mathrm{X} 1, \mathrm{X} 2, \mathrm{Y} \\
\text { to } \mathrm{Z})\end{array}$ & & & \\
\hline $\mathrm{X} 1$ (pYX1) & 0.279 & 2,728 & 0.008 & \multirow[t]{3}{*}{0.482} \\
\hline $\mathrm{X} 2$ (pYX2) & -0.045 & -423 & 0.673 & \\
\hline $\mathrm{Y}(\mathrm{pZY})$ & 0.495 & 4,280 & 0.000 & \\
\hline
\end{tabular}
variables, namely compensation and leadership.

Table 5 Summarized Results 


\section{Indirect Effect and Total Effect}

1. The indirect effect of $\mathrm{X}_{1}$ on $\mathrm{Z}$ through $\mathrm{Y}=\mathrm{pYX} \mathrm{X}_{1} \mathrm{x}$ $\mathrm{pZY}=(0.439) \times(0.495)=0.217$. Thus, the total effect $=\mathrm{pZX} 1+\mathrm{IE}=0.279+0.217=0.496$.

2. The indirect effect of $\mathrm{X}_{2}$ on $\mathrm{Z}$ through $\mathrm{Y}=\mathrm{p} \mathrm{YX}_{2} \mathrm{X}$ $\mathrm{pZY}=(-0.045) \times(0.495)=-0.022$. Thus, the total effect $=\mathrm{pzX}_{2}+\mathrm{IE}=-0.045+-0.0022=-0.047$.

In total, the effects resulted fom substructural 2 can be illustrated in structural equation 2 , that is $Z=\rho Z X 1+$ $\rho Z \mathrm{X} 2+\rho \mathrm{ZY}+\varepsilon 2$ or $\mathrm{Z}=0.279 \mathrm{X} 1-0.045 \mathrm{X} 2+0.495 \mathrm{Y}+$ $\varepsilon 2$. Based on the tests on hypotheses 3,4 , and 5 in structural equation 2, the diagram of empirical path for model $\mathrm{Z}$ is obtained as illustrated in the following figure:

$\varepsilon 1$

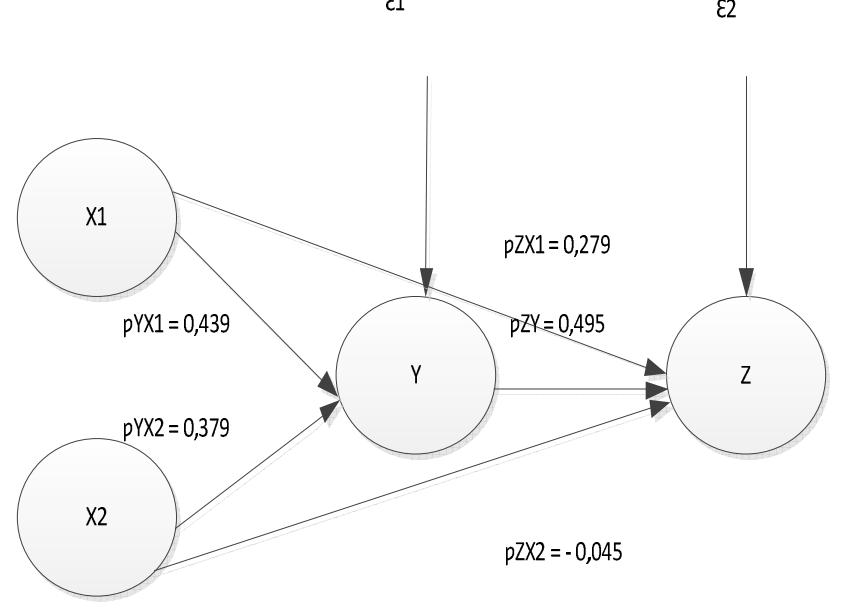

Figure 3 Path Diagram

\section{IV.CONCLUSIONS}

Based on the research that has been carried out, conclusions can be made as follows:

1. Compensation variable significantly influences job satisfaction.

2. Leadership variable significantly influences job satisfaction.

3. Compensation variable significantly influences job performance.

4. Leadership variable does not significantly influence employee's job performance.

5. Job satisfaction variable significantly influences job performance.

\section{Recommendations}

\section{Managerial suggestions}

This research is to know whether compensation and leadership influences job satisfaction and, in turn, influences the performance of HR Managers. From the results of this research, suggestions can be given as follows.
- Salary scale based on competence standard should be made in order that each HR Manager's salary is not too much different from the salary in other companies or industries.

- Trainings or workshops should be held to improve the ability and skill of managers.

- It is necessary to improve job performance by making Key Performance Indicators (KPI) that is suitable with each company.

\section{References}

[1] S. Arzi and L. Farahbod. The Impact of Leadership Style on Job Satisfaction: A Study of Iranian Hotels, Interdiciplinary Journal of Contemporary Research in Business. 2014. Vol. 6, No. 3, pp. 171-186.

[2] D.Belias and K Dimitros.. Leadership and Job Satisfaction - A review. European Scientific Journal, 2014. Vol. 10, No. 8, pp. 24-45.

[3] ML Voon,., M.C., Ngul and N.B, Ayob.The Influence of Leadership Styles on Employees' Job Satisfaction in Public Sector Organization in Malaysia, International Journal of Business, Management, and Social Sciences.2011 Vol. 2, No. 1.

[4] H. Handoko, Manajemen, BPFE UGM, Jogyakarta 2012

[5] Ch Platis, P. Reklitisb, P., and S. Zimeras, Relation Between Job Satisfaction and Job Performance in Healthcare Services, Social and Behavioral Sciences, 2015. Vol. 175, No. 2, pp. 480-487.

[6] S Singh, \& S.K Tiwari.. Relationship Between Motivation and Job Satisfaction of The White Collar Employees: A Case Study, Management Insight. 2011 Vol. VII, No. 2, pp. 31-39.

[7] G Kavita, K Simran,, L Gupta. and K., Sharma Sunil. Impact of Job Satisfaction on Employee Performance, a Challenge for HR Managers in Changing Environment, 2012. International Journal of Scientific Research and Reviews. 1 (3), pp. 88-95.

[8] R Schuler dan E Suzan, Manajemen Sumber Daya Manusia, Menghadapi Abad 21, Edisi Keenam, Jilid 2, Alih Bahasa: Abdul Rosyid dan Peter Remy Pasla, Editor: Yani Sumiharti, Jakarta: Erlangga 1999

[9] J Greenberg, dan R Baron..Perilaku Organisasi.Jakarta :Prentice Hall 2000

[10] S Robbin dan, J Timotty , Prilaku Organisasi (Organizational Behavior), Edisi 12, Edisi Bahasa Indonesia, Jakarta. Salemba Empat. 2000

[11] R Kreitner dan K Angelo.. Perilaku Organisasi, Edisi Bahasa Indonesia. Jakarta 2003: Salemba Empat.

[12] L Colquitt,, Organizational Behavior Improving Performance and Commitment in The Workplace, Mc Graw Hill International Edition. 2009

[13] G.A Yukl..,Leadership in Organizations. Simon \& Schuster (Asia) Pte. Ltd. 1998

[14] R. Noe,, et al.Human Resource Management Gaining Competitive Advantage, 3rd Edition McGraw-Hill. 2010

[15] S Sondang,, Kiat Meningkatkan Produktivitas Kerja, Rineka Cipta Jakarta. 2009

[16] D Darmawan, Didit.. Prinsip-Prinsip Perilaku Organisasi, . Pena Semesta, Surabaya.2013

[17] G. Dessler. Human Resource Management: Global Edition. Pearson Higher Education. 2013

[18] H Simamora Henry, Manajemen Sumber Daya Manusia, Edisi 3, Cetakan 1, Bagian Penerbitan STIE YKPN, Yogyakarta. 2004

[19] M Hasibuan,, Manajemen Sumber Daya Manusia, Penerbit Bumi Akasara. 2007 
[20] R Mathis dan J John . Manajemen Sumber Daya Manusia, Buku 10. Jakarta : Salemba Empat. 2006, 